міждисциплінарних команду поєднанні з керованим дистанційним навчанням тощо.

Висновок. Впровадження англомовного навчання, використання кредитно-модульної системи організації навчального процесу значно стимулюють якість освіти, а існуючі міжнародні контакти колективів кафедр університету допомагають здійснювати підготовку фахівців-медиків на сучасному європейському рівні.

\title{
Література
}

1. Медична освіта у світі та в Україні / [ І. Є. Булах, О. П. Волосовець, В. С. Москаленко та ін.]. - К. : Книга плюс, 2005. - 384 c.

2. Запорожан В. М. Міжнародне науково-освітнє співтовариство як каталізатор реформування / В. М. Запорожан, В. Й. Кресюн, О. В. Чернецька// Проблеми інтеграції української медичної освіти у світовий освітній простір : матеріали Всеукр. навч.-наук. конф. - Тернопіль, 2009. - С. 26-29.

3. Проблеми ефективного впровадження КМСОНП в медичних ВН3 / [В. М. Запорожан, В. Й. Кресюн, Ю. І. Бажора та ін.] // Впровадження кредитно-модульної системи організації навчального процесу у $\mathrm{BM}(\Phi) \mathrm{H} 3$ УКраїни : результати, проблеми та перспективи : матеріали Всеукр. навч.-наук. конф. - Тернопіль, 2010. - С. 176-178.

УДК 378.1:615

\section{ПІДГОТОВКА СТУДЕНТІВ В УМОВАХ КРЕДИТНО-МОДУЛЬНОЇ СИСТЕМИ НАВЧАННЯ НА ВИПУСКОВИХ КАФЕДРАХ СПЕЦАЛЬНОСТІ “ФАРМАЦІЯ”}

\author{
В. П. Черних, І. С. Гриценко, С. В. Огарь, Л. М. Вінник \\ Наџіональний фармачевтичний університет
}

\section{STUDENTS' TRAINING IN THE CONDITIONS OF CREDIT-MODULAR EDUCATIONAL SYSTEM AT THE GRADUATING DEPARTMENTS OF SPECIALITY "PHARMACY"}

\author{
V. P. Chernyh, I. S. Hrytsenko, S. V. Ohar, L. M. Vinnyk \\ National Pharmaceutical University
}

\begin{abstract}
У статті представлено досвід роботи за кредитно-модульною системою у Національному фармацевтичному університеті, описано особливості підготовки студентів на випускових кафедрах спеціальності “Фармація”.

In the article there was presented the experince of work by the credit-modular system in National Pharmaceutical University, it was described the peculiarities of students'training at the graduating departments of speciality "Pharmacy".
\end{abstract}

Вступ. Основним напрямком розвитку освіти в Україні є іiі інтеграція до Європейського освітнього простору, впровадження кредитних технологій на базі Європейської системи трансферу кредитів, стимулювання мобільності й створення умов для працевлаштування випускників на європейському рин- ку праці, розвитку контролю за якістю вищої фармацевтичної освіти.

Основна частина. Контроль за якістю навчання стосується передусім знань студентів і випускників щодо їх компетенції та спроможності відповідати сучасному ринку праці. Якість підготовки студентів спеціальності “Фармація” пов'язана $з$ оцінкою їх

( В. П. Черних, І. С. Гриценко, С. В. Огарь, Л. М. Вінник 
професійних знань, умінь та навичок. Саме це, усвою чергу, пов'язане з об'єктивністю та адекватністю методів контролю за успішністю навчання на кафедpax. Щоб оцінка відображала якість навчання, за умови кредитно-модульної системи організації навчального процесу, необхідними $є$ використання стандартних методів контролю, визначених критеріїв оцінювання та їх достовірність.

Нами було вивчено технологію застосування елементів ECTS у системі оцінювання якості навчання за результатами підсумкового модульного контролю у студентів спеціальності “Фармація” за професійноорієнтованими дисциплінами. Модуль являє собою завершену частину освітньо-професійної програми (навчальної дисципліни, практики, курсової роботи), що реалізується відповідними формами навчального процесу. Тобто це контроль за засвоєнням певного розділу навчальної дисципліни, який спрямований на виконання кінцевих цілей навчання і поєднує теоретичні знання студентів та їх практичні уміння, одержані в процесі проходження виробничої практики та на практичних (лабораторних) заняттях.

За умови кредитно-модульної системи організації навчального процесу кафедрами Національного фармацевтичного університету для проведення підсумкового модульного контролю розроблені та використовуються такі методи оцінювання: тестування, письмова робота, структурований за процедурою контроль професійних практичних навичок, які відповідають вимогам освітньо-кваліфікаційної характеристики. Такий структурований за різними видами підсумковий модульний контроль дає змогу не лише визначити якість професійних знань студента, рівень засвоєння навчального матеріалу, але й зорієнтувати студентів на подальше вдосконалення професійної майстерності.

Окремим модулем визначаються проходження та оцінка виробничої (професійної) практики на четвертому та п'ятому курсах спеціальності “Фармація”, метою якої є закріплення та поглиблення професійних знань та навичок, безпосереднє ознайомлення зі структурою та виробничою діяльністю аптеки.

Висновок. Накопичений нами досвід роботи за кредитно-модульною системою викладання на всіх курсах денної форми навчання свідчить про позитивні наслідки ії впровадження. Зокрема, вона впливає на мотивацію навчання студентів, зацікавленість в отримуваних ними оцінках, що сприяє, у свою чергу, підвищенню їх активності в навчальному процесі, 3 одного боку, та результативності навчання - 3 іншого. Навчання за кредитно-модульною системою спонукає студентів піднімати свій рейтинговий бал за рахунок більш якісної підготовки домашніх завдань та відповідного виконання модульних контрольних і самостійних робіт як важливих складових загальної рейтингової оцінки. Позитивним є також зменшення кількості пропусків занять без поважних причин. Крім того, притаманна системі прозорість оцінювання знань, умінь і навичок стимулює студентів до сумліннішої, а отже, й до якіснішої щоденної праці і в аудиторії, і вдома. 